\title{
Potensi Ikan Teri Jengki (Stolephorus indicus) Sebagai Bahan Media Alternatif untuk Pertumbuhan Bakteri Staphylococcus aureus
}

Tutur Mutmainnah Novitasari, Rohmi, Nurul Inayati

Jurusan Analis Kesehatan, Poltekkes Kemenkes Mataram, Indonesia

\begin{tabular}{l}
\hline Article Info \\
\hline Article history: \\
Received Jan $12^{\text {th }}, 2019$ \\
Revised Feb $20^{\text {th }}, 2019$ \\
Accepted Feb $26^{\text {th }}, 2019$ \\
\hline
\end{tabular}

Keyword:

Indian anchovy

Alternative media

Staphylococcus aureus

\begin{abstract}
Staphylococcus aureus is a Gram-positive bacteria that has a rounded clustered shape resembling grapes (Staphylococcus aureus) and golden colonies (aureus). Manitol Salt Agar (MSA) is a selective and diferential medium for the growth of Gram-positive bacteria. Dried indian anchovy (Stolephorus indicus) has a higher protein than meat, it is expected that Indian anchovy (Stolephorus indicus) can be used as an alternative medium for the growth of Staphylococcus aureus. This study aims to to determine the potential of an Indian anchovy (Stolephorus indicus) as an alternative media material for the growth of Staphylococcus aureus. This research is a true experiment using 5 replications and 5 treatments, MSA medium and Gram-negative (Eschericia coli) bacteria as a controls, MSA media made from Indian anchovy (Stolephorus indicus) concentration 2\%, 3\%, 4\%, 5\% dan $6 \%$. Based on laboratory test results, Staphylococcus aureus can grow at all concentrations. Howefer, the colour of the colonies is best seen in concentrations of $3 \%$ to $6 \%$ with the widest zone of mannitol fermentation and the most concentrated golden yellow colonies at a concentration of 6\%. Based on this results, Indian anchovy (Stolephorus indicus) can be used as an alternative material for the growth of Staphylococcus aureus.
\end{abstract}

Copyright $\odot$ Jurnal Analis Medika Bio Sains All rights reserved.

\begin{abstract}
ABSTRAK
Staphylococcus aureus merupakan bakteri Gram Positif yang memiliki bentuk bulat bergerombol menyerupai buah anggur (Staphylococcus) dan koloni keemasan (aureus). Manitol Salt Agar (MSA) adalah media pertumbuhan selektif dan diferensial untuk bakteri Gram Positif. Ikan teri jengki (Stolephorus indicus) kering memiliki kandungan protein yang lebih tinggi dibandingkan daging maka diharapkan ikan teri jengki (Stolephorus indicus) dapat dijadikan media alternatif untuk pertumbuhan bakteri Staphylococcus aureus. Tujuan dari penelitian ini adalah untuk mengetahui potensi ikan teri jengki (Stolephorus indicus) sebagai bahan media alternatif untuk pertumbuhan bakteri Staphylococcus aureus. Penelitian ini bersifat True Eksperiment dengan menggunakan 5 replikasi dan 5 perlakuan yaitu media MSA sebagai kontrol dan bakteri Gram Negatif (Eschericia coli), media ikan teri jengki (Stolephorus indicus) dengan kosentrasi 2\%,3\%, 4\%,5\% dan 6\%. Berdasarkan hasil uji laboratorium, bakteri Staphylococcus aureus dapat tumbuh pada semua konsentrasi. Namun, warna koloni paling baik terlihat pada konsentrasi $3 \%$ sampai $6 \%$,dengan zona manitol fermentasi terluas dan warna koloni kuning keemasan paling pekat pada konsentrasi 6\%.. Hasil ini membuktikan bahwa ikan teri jengki (Stolephorus indicus) dapat digunakan sebagai bahan alternatif untuk pertumbuhan bakteri Staphylococcus aureus.
\end{abstract}

Kata Kunci : Ikan Teri Jengki, Media Alternatif, Staphylococcus aureus 


\section{Pendahuluan}

Penyakit infeksi merupakan satu kumpulan jenis - jenis penyakit yang disebabkan oleh mikroorganisme, diantaranya adalah virus, bakteri, dan parasit. Penyakit infeksi merupakan salah satu masalah kesehatan yang paling utama di negara-negara berkembang termasuk Indonesia (Aniq et al., 2015). Oleh karena itu, penyakit infeksi saat ini menjadi salah satu masalah kesehatan yang menjadi perhatian serius bukan hanya pada negara berkembang tetapi juga di seluruh dunia. Karena penyakit infeksi telah menjadi salah satu penyebab utama kematian di dunia (Salima, 2015).

Salah satu penyebab terjadinya penyakit infeksi adalah bakteri. Bakteri merupakan salah satu golongan mikroorganisme prokariotik (bersel tunggal) yang hidup berkoloni dan tidak mempunyai selubung inti namun mampu hidup dimana saja (Jawetz et al., 2004). Menurut klasifikasinya, bakteri dibagi menjadi 2 yaitu bakteri Gram positif dan bakteri Gram negatif. Beberapa bakteri Gram positif dan bakteri Gram negatif merupakan flora normal pada tubuh manusia. Flora normal adalah mikroorganisme yang menempati suatu daerah tanpa menimbulkan penyakit pada inang yang ditempati. Pada kulit normal biasanya ditempati sekitar 102-106 $\mathrm{CFU} / \mathrm{cm} 2$ bakteri. Ada juga sebagian dari bakteri Gram positif dan bakteri Gram negatif misalnya Staphylococcus aureus yang dapat menyebakan penyakit jika mencapai jumlah 1.000.000 atau 106 per Gram yang merupakan suatu jumlah yang cukup untuk memproduksi toksin (Holderman et al., 2017).

Staphylococcus aureus merupakan bakteri gram positif yang memiliki bentuk bulat bergerombol menyerupai buah anggur (Staphylococcus) dan koloni keemasan (aureus) (Santika et al., 2013). Spesies ini pernah dianggap sebagai satu satunya patogen dari genusnya. Pembawa Staphylococcus aureus yang asimtomatik sering ditemukan, dan organisme ini ditemukan pada $40 \%$ orang sehat, yakni pada beberapa bagian tubuh seperti di bagian hidung, kulit, ketiak, atau perineum. Staphylococcus aureus mudah tumbuh pada sebagian besar media laboratorium. Bakteri ini toleran terhadap kadar garam yang tinggi, sehingga dapat dibuat media selektif didasarkan pada cara ini (Irianto, 2014).

Media merupakan bahan yang dapat digunakan untuk menumbuhkan dan memperbanyak mikroorganisme seperti bakteri. Penggunaan media sangat penting dalam bidang mikrobiologi yakni untuk isolasi, perhitungan jumlah mikroba, dan pengujian sifat - sifat fisik bakteri sehingga bakteri tersebut dapat teridentifikasi. Nutrisi yang diperlukan oleh mikroorganisme biasanya merupakan senyawa sederhana yang diperoleh dari reaksi pemecahan atau sudah tersedia secara langsung (Wachidah, 2016). Untuk itu media harus mengandung nutrisi yang dibutuhkan oleh mikroorganisme serta memiliki lingkungan yang sesuai agar dapat tumbuh dan berkembangbiak maksimal.

Manitol Salt Agar (MSA) adalah media pertumbuhan selektif dan diferensial yang umum digunakan dalam mikrobiologi. Media ini mengandung garam $(\mathrm{NaCl})$ dalam konsentrasi tinggi yakni sekitar 7,5\% - 10\% sehingga hanya dapat ditumbuhi oleh bakteri yang dapat mentoleransi kadar garam tinggi dan menjadikannya selektif untuk bakteri Grampositif (Staphylococcus dan Micrococcaceae). Selain itu, media ini juga mengandung manitol 
sebagai sumber karbohidrat dan phenol red sebagai pH indikator untuk mendeteksi asam yang dihasilkan oleh Staphylococcus mannitolfermentasi serta ekstrak daging dan pepton sebagai bahan dasar karena merupakan sumber protein dan nitrogen bagi pertumbuhan mikroorganisme (Safitri \& Novel, 2010).

Bahan untuk membuat media MSA berbentuk redihrat (sudah jadi) memiliki harga yang relatif mahal dan media tersebut banyak diproduksi oleh perusahaan asing. Indonesia memiliki sumber daya alam yang melimpah, beberapa diantaranya dapat diperoleh dari produk - produk dari laut dengan harga murah yang dapat menggantikan bahan ekstrak daging dan pepton dalam pembuatan media MSA. Sumber nutrisi alternatif tersebut dapat diperoleh dari ikan teri jengki, bahan ini merupakan bahan yang mudah didapat dan tidak memerlukan biaya yang mahal (Suhartati, Sulistiani \& Nuraini, 2018).

Ikan teri (Stolephorus sp) merupakan salah satu bahan alam yang memiliki kandungan protein yang tinggi. Ikan teri (Stolephorus $s p$ ) memiliki kandungan protein yaitu $42 \mathrm{~g} / 100 \mathrm{~g}$ teri kering asin. Protein ikan teri (Stolephorus $s p$ ) mengandung sejumlah asam amino esensial. Selain itu, ikan teri (Stolephorus sp) juga kaya akan mineral seperti kalsium (Amrullah, 2012).

\section{Metode Penelitian}

Penelitian ini merupakan penelitian true eksperiment yaitu penelitian yang bertujuan untuk mengetahui suatu gejala atau pengaruh yang timbul sebagai akibat dari adanya perlakuan (Notoatmodjo, 2012). Rancangan penelitian yang digunakan adalah Rancangan Acak Lengkap, dengan menggunakan 5 perlakuan yaitu:

$\mathrm{T} 0=$ Media MSA sebagai kontrol positif pertumbuhan.
Ikan teri memiliki banyak jenis salah satunya adalah ikan teri jengki (Stolephorus indicus). Ikan teri jengki (Stolephorus indicus) merupakan ikan teri yang paling banyak dijumpai di Indonesia. Setiap 100 gram ikan teri segar mengandung energi $77 \mathrm{kkal}$, protein 16 gram, lemak 1,0 gram, Kalsium $500 \mathrm{mg}$, zat besi 1,0 mg, vitamin A 47; dan vitamin B1 0,1 mg (Putri, Sukini \& Yodong, 2017).

Selain itu, diketahui dari suatu penelitian bahwa media yang berisi pepton ikan mampu menyebabkan nilai optical density bakteri lebih tinggi dibandingkan dengan pertumbuhan bakteri pada media yang menggunakan pepton komersial (Sari et al., 2017).

Sebelumnya telah dilakukan penelitian dengan menggunakan sumber protein nabati yakni kedelai sebagai sumber nutrisi alami pengganti ekstrak daging dan pepton dengan variasi serbuk kedelai yang digunakan adalah 2 gram, 3 gram, 4 gram, 5 gram dan 6 gram dan didapatkan pertumbuhan bakteri Staphylococcus aureus pada konsentrasi 6 gram/100 ml (Anisa, 2010). Oleh karena itu perlu dilakukan penelitian dengan menjadikan ikan teri jengki (Stolephorus indicus) sebagai bahan dalam pembuatan media alternatif untuk melihat pertumbuhan bakteri Staphylococcus aureus .

$\mathrm{T} 1$ = Penambahan tepung ikan teri jengki (Stolephorus indicus) konsentrasi 2\%, 7,5 gram $\mathrm{NaCl}, 1$ gram manitol, 0,025 gram phenol red, 1,5 gram agar, $100 \mathrm{~mL}$ aquadest.

$\mathrm{T} 2=$ Penambahan tepung ikan teri jengki (Stolephorus indicus) konsentrasi 3\%, 7,5 gram $\mathrm{NaCl}, 1$ gram manitol, 0,025 gram phenol red, 1,5 gram agar, $100 \mathrm{~mL}$ aquadest.

$\mathrm{T} 3$ = Penambahan tepung ikan teri jengki (Stolephorus indicus) konsentrasi 4\%, 7,5 gram $\mathrm{NaCl}, 1$ gram manitol, 0,025 


\footnotetext{
gram phenol red, 1,5 gram agar, $100 \mathrm{~mL}$ aquadest.

$\mathrm{T} 4=$ Penambahan tepung ikan teri jengki (Stolephorus indicus) konsentrasi 5\%, 7,5 gram $\mathrm{NaCl}, 1$ gram manitol, 0,025 gram phenol red, 1,5 gram agar, $100 \mathrm{~mL}$ aquadest.

T5 = Penambahan tepung ikan teri jengki (Stolephorus indicus) konsentrasi 6\%, 7,5 gram $\mathrm{NaCl}, 1$ gram manitol, 0,025 gram phenol red, 1,5 gram agar, $100 \mathrm{~mL}$ aquadest.
}

Teknik pengambilan sampel yang digunakan dalam penelitian ini adalah Purposive Sampling yaitu penelitian yang didasarkan pada suatu pertimbangan tertentu yang dibuat oleh peneliti sendiri, berdasarkan ciri atau sifat-sifat populasi yang sudah diketahui sebelumnya (Notoatmodjo, 2012).

Adapun sampel yang digunakan dalam penelitian memenuhi beberapa kriteria yakni ikan teri jengki kering yang tidak asin, tidak dalam kondisi rusak, tepung ikan teri jengki yang digunakan adalah tepung yang dibuat sendiri dan dalam kondisi baru dibuat, tepung ikan teri jengki memiliki butiran yang tidak menggumpal.

Variabel bebas dari penelitian ini adalah tepung ikan teri jengki dengan konsentrasi yang berbeda - beda dan variable terikat yakni pertumbuhan bakteri Staphylococcus aureus.

Definisi Operasional penelitian ini adalah :

1. Media alternatif berbahan ikan teri jengki (Stolephorus indicus) adalah media yang terbuat dari tepung ikan teri jengki yang ditambahkan 7,5 gram $\mathrm{NaCl}, 1$ gram manitol, 0,025 gram phenol red, 1,5 gram bacto agar, dan $100 \mathrm{ml}$ aquadest.

2. Pertumbuhan bakteri adalah pertumbuhan jumlah bakteri yang dibaca sebagai koloni pada media pertumbuhan.
3. Potensi ikan teri jengki (Stolephorus indicus) adalah kemampuan ikan teri jengki (Stolephorus indicus) sebagai bahan media alternatif dalam menumbuhkan bakteri Staphylococus aureus.

Instrumentasi dan bahan penelitian : Petri Dish, Neraca Analitik, Beaker Glass, Erlenmeyer, Batang Pengaduk, Hot Plate, Blender, Pipet Ukur ,Pipet Tetes, Gelas Ukur, Mikropipet,Tip, Inkubator, Ose Bengkok, Tabung Reaksi, Lampu Spiritus, Oven, Autoklaf, Ph Meter, Saringan, Baskom, Korek Api, Karet, Kapas, Kasa, Tissue, Alkohol 70\%, Ikan Teri Jengki (Stolephorus indicus), Aquadest, Agar, Manitol, $\mathrm{NaCl}$, Phenol Red, $\mathrm{H}_{2} \mathrm{O}_{2}$ Plasma Sitrat, Media MSA, Isolat Bakteri Staphylococus aureus ATCC 25923, Isolat Bakteri Eschericia coli.

Cara pengumpulan data :

1. Tahap persiapan

a. Sterilisasi alat

Alat - alat yang akan digunakan dalam penelitian harus disterilisasi agar alat - alat tersebut terbebas dari mikroorganisme yang dapat menghambat penelitian. Berikut cara sterilisasi alat - alat laboratorium yang akan digunakan dalam penelitian (Dwidjoseputro, 2005) :

1) Tabung reaksi, Erlenmeyer dan beaker glass

a) Disemprotkan alkohol $70 \%$ ke permukaan dalam dan luar alat kemudiandikeringkan menggunakan tisu.

b) Disumbat leher erlenmeyer dan lubang tabung reaksi serta beaker glass menggunakan sumbat kapas sedemikian rupa sehingga kapas tidak mudah lepas dari tabung reaksi yang disterilkan. 
c) Dibungkus dengan kertas coklat dan diikat dengan karet untuk menghindari meresapnya air dari autoklaf ke dalam alat yang disterilkan.

d) Dilakukan pengecekan air pada autoklaf dan memasukkan alat - alat ked ala autoklaf selama \pm 15 menit dalam suhu $121^{\circ} \mathrm{C}$.

\section{2) Petri dish}

a) Dibungkus petri dish menggunakan kertas koran.

b) Dimasukkan petri dish tersebut kedalam kertas coklat dan diikat dengan karet untuk menghindari meresapnya air dari autoklaf ke dalam alat yang disterilkan.

c) Dimasukkan ke dalam autoklaf.

2. Pengolahan Ikan Teri Jengki (Stolephorus indicus)

a) Ikan teri dibersihkan dan dicuci terlebih dahulu sebanyak $0,5 \mathrm{~kg}$.

b) Ikan teri yang telah bersih kemudian dikeringkan menggunakan oven dengan suhu $50^{\circ} \mathrm{C}$ selama \pm 2 hari.

c) Ikan kemudian dihancurkan menggunakan blender

d) Ikan teri yang telah kering kemudian dihancurkan dan diayak dengan ayakan ukuran 80 mesh hingga mendapatkan butiran yang halus.

3. Pembuatan media

a. Media MSA sebagai kontrol

1) Ditimbang media MSA sebanyak 5,55 gram.

2) Dimasukkan media MSA tersebut ke dalam Erlenmeyer $100 \mathrm{~mL}$, ditambahkan aquadest sebanyak 50 $\mathrm{mL}$.

3) Dipanaskan diatas hot plate sambil diaduk sampai larut.

4) Ditutup lubang erlenmeyer dengan sumbat kapas, dibungkus erlenmeyer dengan kertas coklat dan disterilkan dengan autoclave pada suhu $121^{\circ} \mathrm{C}$ selama 15 menit.

5) Larutan yang telah steril dimasukkan ke dalam petri dish steril $\pm 15 \mathrm{~mL}$, dan dibiarkan sampai dingin dan siap digunakan (Novel, 2010).

b. Media alternatif berbahan ikan teri jengki (Stolephorus indicus) dengan konsentrasi $6 \%$

1) Ditimbang tepung ikan teri jengki sebanyak 6 gram dan dimasukkan ke dalam erlenmeyer $250 \mathrm{~mL}$, lalu ditambahkan aquadest sebanyak 100 $\mathrm{mL}$.

2) Dipanaskan diatas hot plate sambil diaduk sampai homogen.

3) Media didiamkan sebentar hingga bagian - bagian sisa dari ikan teri yang tidak dapat hancur mengendap.

4) Lalu saring sari / kaldu tepung ikan teri jengki hingga tidak ada lagi endapan ke dalam Erlenmeyer lainnya.

5) Ditambahkan 7,5 gram $\mathrm{NaCl}, 1$ gram manitol, 0,025 gram phenol red, 1,5 gram agar, dan $100 \mathrm{~mL}$ aquadest, lalu diaduk hingga homogen.

6) Ukur pH pada media dan disesuaikan menjadi $\pm 7,4$, jika tidak netral dapat ditambahkan $\mathrm{HCl} / \mathrm{NaOH}$.

\footnotetext{
${ }^{\square}$ Korespodensi: Tutur Mutmainnah Novitasari, titanelang@ gmail.com, 081236301645, Jurnal Analis Medika Bio Sains, Volume X No. X, Februari X|
} 
7) Ditutup lubang erlenmeyer dengan sumbat kapas, dibungkus erlenmeyer dengan kertas coklat dan disterilkan dengan autoclave pada suhu $121^{\circ} \mathrm{C}$ selama 15 menit.

8) Larutan yang telah steril dimasukkan ke dalam petri dish steril $\pm 15 \mathrm{~mL}$, dan dibiarkan sampai dingin dan siap digunakan.

c. Media alternatif berbahan ikan teri jengki (Stolephorus indicus) dengan konsentrasi $5 \%$

1) Ditimbang tepung ikan teri jengki sebanyak 5 gram dan dimasukkan ke dalam erlenmeyer $250 \mathrm{~mL}$, lalu ditambahkan aquadest sebanyak 100 $\mathrm{mL}$.

2) Dipanaskan diatas hot plate sambil diaduk sampai homogen.

3) Media didiamkan sebentar hingga bagian - bagian sisa dari ikan teri yang tidak dapat hancur mengendap.

4) Lalu saring sari / kaldu tepung ikan teri jengki hingga tidak ada lagi endapan ke dalam Erlenmeyer lainnya.

5) Ditambahkan 7,5 gram $\mathrm{NaCl}, 1$ gram manitol, 0,025 gram phenol red, 1,5 gram agar, dan $100 \mathrm{~mL}$ aquadest, lalu diaduk hingga homogen.

6) Ukur $\mathrm{pH}$ pada media dan disesuaikan menjadi $\pm 7,4$, jika tidak netral dapat ditambahkan $\mathrm{HCl} / \mathrm{NaOH}$.

7) Ditutup lubang erlenmeyer dengan sumbat kapas, dibungkus erlenmeyer dengan kertas coklat dan disterilkan dengan autoclave pada suhu $121^{\circ} \mathrm{C}$ selama 15 menit.

8) Larutan yang telah steril dimasukkan ke dalam petri dish steril $\pm 15 \mathrm{~mL}$, dan dibiarkan sampai dingin dan siap digunakan.

d. Media alternatif berbahan ikan teri jengki (Stolephorus indicus) dengan konsentrasi $4 \%$

1) Ditimbang tepung ikan teri jengki sebanyak 4 gram dan dimasukkan ke dalam erlenmeyer $250 \mathrm{~mL}$ lalu ditambahkan aquadest sebanyak 100 $\mathrm{mL}$.

2) Dipanaskan diatas hot plate sambil diaduk sampai homogen.

3) Media didiamkan sebentar hingga bagian - bagian sisa dari ikan teri yang tidak dapat hancur mengendap.

4) Lalu saring sari / kaldu tepung ikan teri jengki hingga tidak ada lagi endapan ke dalam Erlenmeyer lainnya.

5) Ditambahkan 7,5 gram $\mathrm{NaCl}, 1$ gram manitol, 0,025 gram phenol red, 1,5 gram agar, dan $100 \mathrm{~mL}$ aquadest, lalu diaduk hingga homogen.

6) Ukur $\mathrm{pH}$ pada media dan disesuaikan menjadi $\pm 7,4$, jika tidak netral dapat ditambahkan $\mathrm{HCl} / \mathrm{NaOH}$.

7) Ditutup lubang erlenmeyer dengan sumbat kapas, dibungkus erlenmeyer dengan kertas coklat dan disterilkan dengan autoclave pada suhu $121^{\circ} \mathrm{C}$ selama 15 menit.

8) Larutan yang telah steril dimasukkan ke dalam petri dish steril $\pm 15 \mathrm{~mL}$, dan dibiarkan sampai dingin dan siap digunakan.

e. Media alternatif berbahan ikan teri jengki (Stolephorus indicus) dengan konsentrasi $3 \%$ 
1) Ditimbang tepung ikan teri jengki sebanyak 3 gram dan dimasukkan ke dalam erlenmeyer $250 \mathrm{~mL}$ lalu ditambahkan aquadest sebanyak 100 $\mathrm{mL}$.

2) Dipanaskan diatas hot plate sambil diaduk sampai homogen.

3) Media didiamkan sebentar hingga bagian - bagian sisa dari ikan teri yang tidak dapat hancur mengendap.

4) Lalu saring sari / kaldu tepung ikan teri jengki hingga tidak ada lagi endapan ke dalam Erlenmeyer lainnya.

5) Ditambahkan 7,5 gram $\mathrm{NaCl}, 1$ gram manitol, 0,025 gram phenol red, 1,5 gram agar, dan $100 \mathrm{~mL}$ aquadest, lalu diaduk hingga homogen.

6) Ukur $\mathrm{pH}$ pada media dan disesuaikan menjadi $\pm 7,4$, jika tidak netral dapat ditambahkan $\mathrm{HCl} / \mathrm{NaOH}$.

7) Ditutup lubang erlenmeyer dengan sumbat kapas, dibungkus erlenmeyer dengan kertas coklat dan disterilkan dengan autoclave pada suhu $121^{\circ} \mathrm{C}$ selama 15 menit.

8) Larutan yang telah steril dimasukkan ke dalam petri dish steril $\pm 15 \mathrm{~mL}$, dan dibiarkan sampai dingin dan siap digunakan.

f. Media alternatif berbahan ikan teri jengki (Stolephorus indicus) dengan konsentrasi $2 \%$

1) Ditimbang tepung ikan teri jengki sebanyak 2 gram dan dimasukkan ke dalam erlenmeyer $250 \mathrm{~mL}$ lalu ditambahkan aquadest sebanyak 100 $\mathrm{mL}$.
2) Dipanaskan diatas hot plate sambil diaduk sampai homogen.

3) Media didiamkan sebentar hingga bagian - bagian sisa dari ikan teri yang tidak dapat hancur mengendap.

4) Lalu saring sari / kaldu tepung ikan teri jengki hingga tidak ada lagi endapan ke dalam Erlenmeyer lainnya.

5) Ditambahkan 7,5 gram $\mathrm{NaCl}, 1$ gram manitol, 0,025 gram phenol red, 1,5 gram agar, dan $100 \mathrm{~mL}$ aquadest, lalu diaduk hingga homogen.

6) Ukur pH pada media dan disesuaikan menjadi $\pm 7,4$, jika tidak netral dapat ditambahkan $\mathrm{HCl} / \mathrm{NaOH}$.

7) Ditutup lubang erlenmeyer dengan sumbat kapas, dibungkus erlenmeyer dengan kertas coklat dan disterilkan dengan autoclave pada suhu $121^{\circ} \mathrm{C}$ selama 15 menit.

8) Larutan yang telah steril dimasukkan ke dalam petri dish steril $\pm 15 \mathrm{~mL}$, dan dibiarkan sampai dingin dan siap digunakan.

4. Penanaman Staphylococcus aureus ATCC 25923 pada media MSA kontrol.

a. Diambil koloni dari media NAP menggunakan ose bulat steril.

b. Digoreskan ose pada media MSA

c. Inkubasi pada suhu $37^{\circ} \mathrm{C}$ selama 24 jam.

d. Diamati makroskopis koloni yang tumbuh pada media MSA.

e. Dilakukan pewarnaan Gram kembali dari koloni yang tumbuh pada pada media MSA.

\footnotetext{
Korespodensi: Tutur Mutmainnah Novitasari, titanelang@gmail.com, 081236301645, Jurnal Analis Medika Bio Sains, Volume X No. X, Februari X |
} 
5. Penanaman bakteri Staphylococcus aureus ATCC 25923 pada media MSA berbahan ikan teri jengki (Stolephorus indicus).

a. Disiapkan alat dan bahan yang akan digunakan.

b. Diambil 1 ose dari media NAP menggunakan ose bulat steril lalu tanam pada media MSA berbahan ikan teri jengki (Stolephorus indicus) konsentrasi 2\%, 3\%, $4 \%, 5 \%$, dan $6 \%$.

c. Inkubasi selama 24 jam.

d. Diamati makroskopis dan mikroskopis dari koloni yang tumbuh pada masing - masing media MSA berbahan ikan teri jengki (Stolephorus indicus) konsentrasi 2\%, 3\%, $4 \%, 5 \%$, dan $6 \%$.

6. Penanaman bakteri kontrol Gram negatif (Eschericia coli) pada media MSA berbahan ikan teri jengki (Stolephorus indicus).

a. Disiapkan alat dan bahan yang akan digunakan.

b. Diambil 1 ose dari media NAP menggunakan ose bulat steril lalu tanam pada media MSA berbahan ikan teri jengki

\section{Hasil Penelitian dan Pembahasan}

Koloni yang tumbuh pada media MSA berbahan ikan teri jengki (Stolephorus indicus) diamati secara makroskopis dan mikroskopis. Secara makroskopis terlihat adanya pertumbuhan koloni bakteri dengan karakteristik koloni berukuran 1 - $3 \mathrm{~mm}$, permukaan halus dan berwarna kuning keemasan serta terjadi perubahan warna pada media MSA berbahan ikan teri jengki (Stolephorus indicus) konsentrasi 2\%, $3 \%, 4 \%, 5 \%$ dan $6 \%$ dari merah menjadi kuning. Pada daerah yang ditanami bakteri kontrol Eschericia coli tidak terdapat pertumbuhan
(Stolephorus indicus) konsentrasi 2\%, 3\%, $4 \%, 5 \%$, dan $6 \%$.

c. Inkubasi selama 24 jam.

d. Diamati makroskopis dari koloni yang tumbuh pada masing - masing media MSA berbahan ikan teri jengki (Stolephorus indicus) konsentrasi 2\%, 3\%, 4\%, 5\%, dan $6 \%$.

7. Pengamatan koloni bakteri Staphylococcus aureus

a. Diambil media MSA berbahan ikan teri jengki konsentrasi 6\%, 5\%, 4\%, 3\%, dan $2 \%$ dari inkubator.

b. Diamati pertumbuhan koloni bakteri Staphylococcus aureus pada media MSA berbahan ikan teri jengki konsentrasi $6 \%$, $5 \%, 4 \%, 3 \%$, dan $2 \%$.

c. Dimasukkan data pengamatan media yang ditumbuhi bakteri Staphylococcus aureus pada tabel pengamatan.

Analisis data yang digunkan dalam penelitian ini adalah analisis data secara deskriptif.

bakteri dan tidak terjadi perubahan warna media. Sedangkan pada pengamatan mikroskopis terlihat penampakan bakteri Gram positif coccus dan bergerombol,

Pemeriksaan dilanjutkan dengan uji katalase dan uji koagulase. Pada uji katalase setelah penambahan reagen hidrogen peroksida $\left(\mathrm{H}_{2} \mathrm{O}_{2}\right)$ timbul buih atau gelembung gas pada semua konsentrasi media MSA berbahan ikan teri jengki (Stolephorus indicus) yang menandakan uji katalase positif.Hasil yang serupa juga didapatkan pada uji koagulase, yakni positif pada semua 
konsentrasi media MSA berbahan ikan teri jengki (Stolephorus indicus) yang ditandai dengan terbentuknya gumpalan seperti pasir halus.

Hasil penelitian pertumbuhan bakteri Staphylococcus aureus pada media berbahan ikan teri jengki dengan metode streak plate test pada setiap perlakuan didapatkan hasil seperti terlihat pada tabel 1. Hasil makroskopis dan mikroskopis koloni bakteri Staphylococcus aureus serta hasil uji katalase dan koagulase dapat dilihat pada gambar 1, 2 dan 3 .

Tabel 1. Hasil pertumbuhan bakteri Staphylococcus aureus pada media MSA berbahan ikan teri jengki dan media MSA kontrol.

\begin{tabular}{|c|c|c|c|c|}
\hline \multirow[t]{2}{*}{ Variasi } & \multicolumn{2}{|l|}{ Pengamatan } & \multicolumn{2}{|c|}{ Uji Penegasan } \\
\hline & Makroskopis & Miroskopis & Katalase & Koagulase \\
\hline $2 \%$ & $\begin{array}{l}\text { - Konsistensi : Lunak } \\
\text { - Warna : Kuning agak pucat (Manitol } \\
\text { fermenter sedang) } \\
\text { - Permukaan : Halus } \\
\text { - Tepi : Rata } \\
\text { - Elevasi : Cembung } \\
\text { - Ukuran : } 1-2 \mathrm{~mm}\end{array}$ & $\begin{array}{l}\text { Gram positif } \\
\text { Coccus } \\
\text { bergerombol }\end{array}$ & Positif & $\begin{array}{l}\text { Positif (terjadi } \\
\text { aglutinasi) }\end{array}$ \\
\hline $3 \%$ & $\begin{array}{l}\text { - Konsistensi : Lunak } \\
\text { - Warna : Kuning keemasan (Manitol } \\
\text { fermenter sedang) } \\
\text { - Permukaan : Halus } \\
\text { - Tepi : Rata } \\
\text { - Elevasi : Cembung } \\
\text { - Ukuran : } 1-2 \mathrm{~mm}\end{array}$ & $\begin{array}{l}\text { Gram positif } \\
\text { Coccus } \\
\text { bergerombol }\end{array}$ & Positif & $\begin{array}{l}\text { Positif (terjadi } \\
\text { aglutinasi) }\end{array}$ \\
\hline $4 \%$ & $\begin{array}{l}\text { - Konsistensi : Lunak } \\
\text { - Warna : Kuning keemasan (Manitol } \\
\text { fermenter sedang) } \\
\text { - Permukaan : Halus } \\
\text { - Tepi : Rata } \\
\text { - Elevasi : Cembung } \\
\text { - Ukuran : } 1-2 \mathrm{~mm}\end{array}$ & $\begin{array}{l}\text { Gram positif } \\
\text { Coccus } \\
\text { bergerombol }\end{array}$ & Positif & $\begin{array}{l}\text { Positif (terjadi } \\
\text { aglutinasi) }\end{array}$ \\
\hline $5 \%$ & $\begin{array}{l}\text { - Konsistensi : Lunak } \\
\text { - Warna : Kuning keemasan (Manitol } \\
\text { fermenter sedang) } \\
\text { - Permukaan : Halus } \\
\text { - Tepi : Rata } \\
\text { - Elevasi : Cembung } \\
\text { - Ukuran : } 1-3 \mathrm{~mm}\end{array}$ & $\begin{array}{l}\text { Gram positif } \\
\text { Coccus } \\
\text { bergerombol }\end{array}$ & Positif & $\begin{array}{l}\text { Positif (terjadi } \\
\text { aglutinasi) }\end{array}$ \\
\hline $6 \%$ & $\begin{array}{l}\text { - } \text { Konsistensi : Lunak } \\
\text { - Warna : Kuning keemasan (Manitol } \\
\text { fermenter luas) } \\
\text { - Permukaan : Halus } \\
\text { - Tepi : Rata } \\
\text { - Elevasi : Cembung } \\
\text { - Ukuran : } 1-3 \mathrm{~mm}\end{array}$ & $\begin{array}{l}\text { Gram positif } \\
\text { Coccus } \\
\text { bergerombol }\end{array}$ & Positif & $\begin{array}{l}\text { Positif (terjadi } \\
\text { aglutinasi) }\end{array}$ \\
\hline Kontrol & $\begin{array}{l}\text { - Konsistensi : Lunak } \\
\text { - Warna : Kuning keemasan (Manitol } \\
\text { fermenter luas) } \\
\text { - Permukaan : Halus } \\
\text { - Tepi : Rata } \\
\text { - Elevasi : Cembung } \\
\text { - Ukuran : } 1-3 \mathrm{~mm}\end{array}$ & $\begin{array}{l}\text { Gram positif } \\
\text { Coccus } \\
\text { bergerombol }\end{array}$ & Positif & $\begin{array}{l}\text { Positif (terjadi } \\
\text { aglutinasi) }\end{array}$ \\
\hline
\end{tabular}



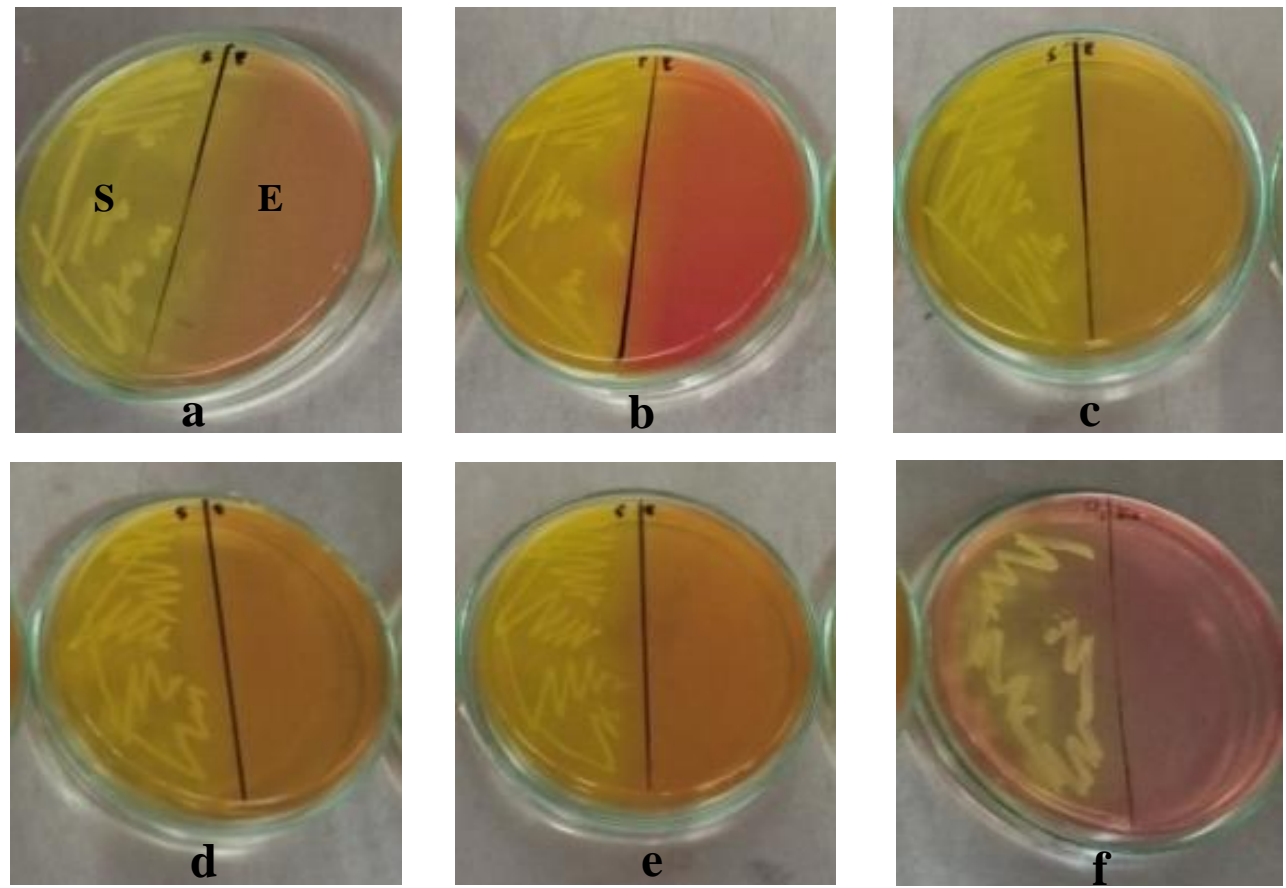

Gambar 3. Makroskopis koloni Staphylococcus aureus pada media MSA berbahan ikan teri jengki dan media MSA kontrol, (a) media MSA berbahan ikan teri jengki konsentrasi 2\% (S) daerah penanaman Staphylococcus aureus (E) daerah penanaman Eschericia coli, (b) media MSA berbahan ikan teri jengki konsentrasi 3\%, (c) media MSA berbahan ikan teri jengki konsentrasi 4\%, (d) media MSA berbahan ikan teri jengki konsentrasi 5\%, (e) media MSA berbahan ikan teri jengki konsentrasi 6\%, (f) media MSA kontrol.
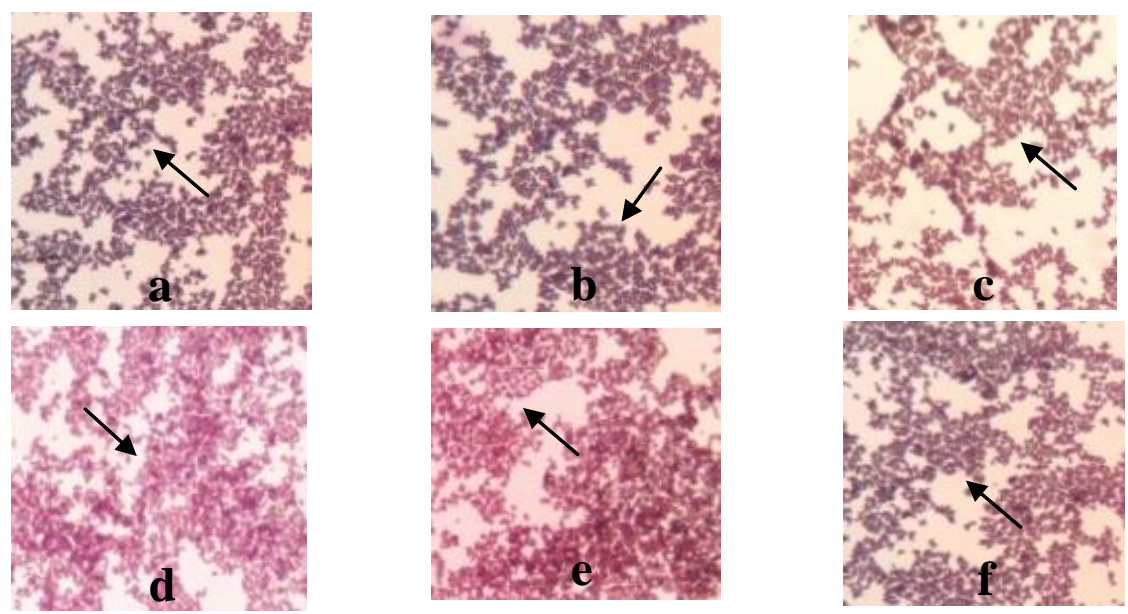

Gambar 4. Mikroskopis koloni Staphylococcus aureus pada media MSA berbahan ikan teri jengki dan MSA kontrol yang ditunjukkan dengan panah, (a) media MSA berbahan ikan teri jengki konsentrasi 2\%. (b) media MSA berbahan ikan teri jengki konsentrasi 3\%, (c) media MSA berbahan ikan teri jengki konsentrasi 4\%, (d) media MSA berbahan ikan teri jengki konsentrasi 5\%, (e) media MSA berbahan ikan teri jengki konsentrasi 6\%,(f) media MSA kontrol. 

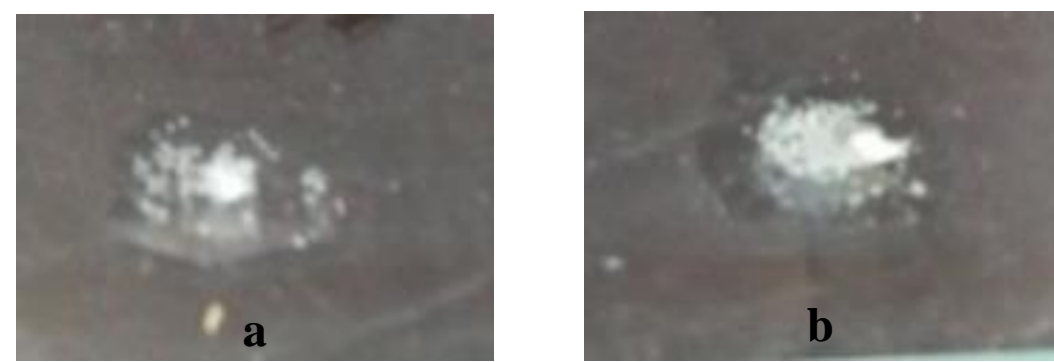

Gambar 5. (a) Uji Katalase pada koloni media MSA berbahan ikan teri jengki dan media MSA kontrol menunjukkan hasil positif ditandai dengan adanya buih setelah dihomogenkan dengan larutan peroksida, (b) uji koagulase pada koloni media MSA berbahan ikan teri jengki dan media MSA kontrol menunjukkan hasil positif ditandai dengan adanya gumpalan setelah dihomogenkan dengan plasma sitrat.

\section{Pembahasan}

Media pertumbuhan mikroorganisme adalah suatu bahan yang konsistensinya terdiri dari campuran zat - zat makanan (nutrisi) yang diperlukan mikroorganisme untuk pertumbuhannya. Mikroorganisme memanfaatkan nutrisi media berupa molekul - molekul kecil yang dirakit untuk menyusun komponen sel ( Machmud, 2008 ).

Setiap organisme memiliki kebutuhan nutrisi yang berbeda serta dalam jumlah yang berbeda (Madigan et al., 2009). Untuk itu dalam setiap media pertumbuhan bakteri, haruslah mengandung nutrisi yang cukup untuk perkembangan dan pertumbuhan bakteri.

Manitol Salt Agar (MSA) adalah media pertumbuhan selektif dan diferensial yang umum digunakan dalam mikrobiologi. Media ini mengandung garam $(\mathrm{NaCl})$ dalam konsentrasi tinggi yakni sekitar 7,5\% - 10\% sehingga hanya dapat ditumbuhi oleh bakteri yang dapat mentoleransi kadar garam tinggi dan menjadikannya selektif untuk bakteri Grampositif (Staphylococcus dan Micrococcaceae). Selain itu, media ini juga mengandung manitol sebagai sumber karbohidrat dan phenol red sebagai $\mathrm{pH}$ indikator untuk mendeteksi asam yang dihasilkan oleh Staphylococcus mannitolfermentasi serta ekstrak daging dan pepton sebagai bahan dasar karena merupakan sumber protein dan nitrogen bagi pertumbuhan mikroorganisme (Safitri \& Novel, 2010).

Penelitian ini dilakukan berdasarkan penelitian sebelumnya mengenai media MSA alternatif dengan menggunakan sumber protein yang berbeda yakni kedelai yang memberikan hasil bahwa bakteri Staphylococcus aureus dapat tumbuh pada media MSA berbahan kedelai mulai dari konsentrasi 2\%, 3\%, 4\%, 5\% dan $6 \%$.

Selain itu penelitian ini juga didasarkan pada penelitian dengan menggunakan pepton dari hasil hidrolisis jeroan ikan tongkol sebagai pengganti pepton standar yang mana pada konsentrasi $2 \%$ pepton jeroan ikan tongkol telah berhasil menumbuhkan bakteri Staphylococcus aureus.

Pada penelitian ini bakteri Staphylococcus aureus ATCC 25923 ditanam pada media MSA berbahan ikan teri jengki kemudian diamati pertumbuhannya secara makroskopis dan mikroskopis. Secara makroskopis pertumbuhan

\footnotetext{
${ }^{\square}$ Korespodensi: Tutur Mutmainnah Novitasari, titanelang@gmail.com, 081236301645, Jurnal Analis Medika Bio Sains, Volume X No. X, Februari X |
} 
dan perkembangan bakteri Staphylococcus aureus terlihat optimal dan tidak ada perbedaan signifikan dengan media MSA standar. Hal ini dapat dinilai berdasarkan pada ukuran, bentuk koloni, warna, elevasi, permukaan, pinggiran dan sifat manitol fermenter dari koloni yang tumbuh pada media.

Sedangkan penilaian secara mikroskopis dilakukan dengan melakukan pewarnaan Gram dan menghasilkan bakteri berwarna ungu yang berarti anggota bakteri Gram positif serta memiliki bentuk coccus bergerombol seperti buah anggur.

Koloni yang tumbuh pada media MSA berbahan ikan teri jengki terlihat besar dan nyata serta mudah diamati sama seperti koloni yang tumbuh pada media MSA standar. Perbedaan koloni pada media MSA berbahan ikan teri jengki dan media MSA standar hanya pada zona manitol fermentasi, warna koloni dan ukuran koloni. Media MSA berbahan ikan teri jengki konsentrasi $6 \%$ merupakan media dengan zona manitol fermentasi terluas serta memilki warna kuning keemasan yang lebih nyata.

Hal tersebut dikarenakan nutrisi atau sumber protein yang terkandung dalam ikan teri jengki yang tinggi, serta kandungan nutrisi yang lain seperti lemak, vitamin dan mineral (Syaifudin et $a l$, 2008). Selain itu ikan teri jengki juga mengandung asam amino esensial seperti isoleusin, leusin, lisin dan valin yang mana asam amino ini digunakan oleh bakteri sebagai sumber nitrogen untuk tumbuh dan berkembang (Saputra \& Nurhayati, 2013).

Variasi tepung ikan teri jengki (Stolephorus indicus) yang digunakan tidak memiliki pengaruh signifikan terhadap pertumbuhan bakteri Staphylococcus aureus, sehingga proses metabolisme bakteri berlangsung cepat dan optimal pada semua konsentrasi. Hal ini berdampak positif pada proses pembelahan sel yang berjalan baik sehingga menyebabkan ukuran koloni semakin besar dan cepat dalam proses memfermentasikan manitol. Dalam kondisi nutrisi yang baik waktu yang dibutuhkan untuk pertumbuhan bakteri relatif cepat, sebaliknya jika nutrisi yang dibutuhkan tidak melimpah, sel-sel harus menyesuaikan dengan lingkungan dan pembentukan enzim - enzim untuk mengurai substrat membutuhkan waktu yang lebih lama (Anisah; Rahayu, 2005

Pada penelitian ini media MSA berbahan ikan teri jengki menggunakan bakteri kontrol yakni bakteri Eschericia coli yang berfungsi untuk menguji apakah media MSA berbahan ikan teri jengki dapat menghambat bakteri Gram negatif dengan baik atau tidak.

Setelah dilakukan pengamatan, terlihat bahwa bakteri Eschericia coli tidak tumbuh pada kontrol negatif media MSA berbahan ikan teri jengki, yang ditandai dengan tidak adanya koloni yang tumbuh serta tidak terjadi perubahan warna pada bagian yang telah ditanami bakteri Eschericia coli setelah diinkubasi pada suhu $37^{\circ} \mathrm{C}$ selama 24 jam. Hal tersebut disebabkan oleh kandungan garam $\mathrm{NaCl}$ pada media dengan konsentrasi cukup tinggi yakni $7,5 \%$ sebagai penghambat pertumbuhan bakteri lainnya (Rahmi et al., 2015).

Kebanyakan bakteri tidak dapat bertahan hidup dilingkungan dengan kadar garam sangat tinggi (hipertonik), kecuali genus Staphylococcus mampu beradaptasi dengan lingkungan tinggi kadar garam dan tumbuh baik di media MSA ini (Saftri, 2010). Sedangkan Eschericia coli termasuk bakteri Gram negatif, dan tidak tahan terhadap kadar garam yang sangat tinggi. Sehingga Eschericia coli tidak dapat tumbuh dan fungsi media MSA sebagai media selektif dengan 
sumber protein diganti tepung ikan teri jengki berfungsi dengan baik.

\section{Kesimpulan}

Berdasarkan penelitian yang telah dilakukan dapat disimpulkan bahwa :

1. Pertumbuhan bakteri Staphylococcus aureus pada media alternatif ikan teri jengki (Stolephorus indicus) konsentrasi $2 \%$ setelah inkubasi selama 24 jam adalah memiliki konsistensi lunak, berwarna kuning agak pucat, manitol fermenter sedang, permukaan halus, tepi rata, cembung, dan berukuran $1-2 \mathrm{~mm}$.

2. Pertumbuhan bakteri Staphylococcus aureus pada media alternatif ikan teri jengki (Stolephorus indicus) konsentrasi $3 \%$ setelah inkubasi selama 24 jam adalah memiliki konsistensi lunak, berwarna kuning keemasan, manitol fermenter sedang, permukaan halus, tepi rata, cembung, dan berukuran $1-2 \mathrm{~mm}$.

3. Pertumbuhan bakteri Staphylococcus aureus pada media alternatif ikan teri jengki (Stolephorus indicus) konsentrasi $4 \%$ setelah inkubasi selama 24 jam adalah memiliki konsistensi lunak, berwarna kuning keemasan, manitol fermenter sedang, permukaan halus, tepi rata, cembung, dan berukuran $1-2 \mathrm{~mm}$.

4. Pertumbuhan bakteri Staphylococcus aureus pada media alternatif ikan teri jengki (Stolephorus indicus) konsentrasi $5 \%$ setelah inkubasi selama 24 jam adalah memiliki konsistensi lunak, berwarna kuning keemasan, manitol fermenter sedang, permukaan halus, tepi rata, cembung, dan berukuran $1-3 \mathrm{~mm}$.

5. Pertumbuhan bakteri Staphylococcus aureus pada media alternatif ikan teri jengki (Stolephorus indicus) konsentrasi $6 \%$ setelah inkubasi selama 24 jam adalah memiliki konsistensi lunak, berwarna kuning keemasan, manitol fermenter luas, permukaan halus, tepi rata, cembung, dan berukuran $1-3 \mathrm{~mm}$.

6. Pertumbuhan bakteri Staphylococcus aureus pada media alternatif ikan teri jengki (Stolephorus indicus) dengan media MSA kontrol secara makroskopis dan mikroskopis tidak memiliki perbedaan yang signifikan, tetapi konsentrasi yang paling mendekati adalah konsentrasi $6 \%$.

\section{Daftar Pustaka}

Ali Hanafiah, Kemas. 2010. Rancangan Percobaan Teori \& Aplikasi, Palembang : USP.

Amrullah, F. 2012. Kadar Protein dan Ca pada Ikan Teri Asin Hasil Pengasinan Dengan Abu Pelepah Kelapa .Naskah Publikasi Ilmiah, Surakarta. hal. 22

Aniq, A. et al. 2015. Sistem Pakar Untuk Mendiagnosis Penyakit Infeksi Menggunakan Forward Chaining, Journal Itsmart, 4(1) : hal. 43-47

Anisa, A. 2010. Pemanfaatan Serbuk Kacang Kedelai Sebagai Media Alternatif, Politeknik Kesehatan.

\footnotetext{
${ }^{\square}$ Korespodensi: Tutur Mutmainnah Novitasari, titanelang@ gmail.com, 081236301645, Jurnal Analis Medika Bio Sains, Volume X No. X, Februari X |
} 
Anisah. 2015. Media Alternatif untuk Pertumbuhan Bakteri Menggunakan Sumber Karbohidrat yang Berbeda. Universitas Muhammadiyah Surakarta, hal. 44

Anita Yandi Putri. 2017. Perbandingan Efektivitas Ekstrak Ikan Teri Jengki ( $S$. insularis) dan Flour Topikal dalam Meningkatkan Kekerasan Permukaan Email (In Vitro). Semarang.

Cappucino, J. G. \& Sherman, N. 2014. Manual Laboratorium Mikrobiologi. $8^{\text {th }}$ edn. Edited by J. Manurung \& $\mathrm{H}$. Vidhayanti. Jakarta: Penerbit Buku Kedokteran EGC.

Harris, A. M. 2014. Studi Komparasi Variasi Media Kultur Terhadap Pertumbuhan Populasi Bakteri Bacillus subtilis dan Bacillus licheniformis untuk Probiotik Unggas.

Hidayah, N. 2018. Pembuatan Patty Burger Berbahan Dasar Ikan Teri Basah (Stolephorus sp), Politeknik Negeri Balikpapan, hal. 90

Holderman, M. V et al. 2017. Identification of Bacteria In Handrail Escalator, 17(1): hal. 13-18

Indrawan, D. P. 2017. Analisa Klorin pada Ikan Teri di Balai Laboratorium Kesehatan Daerah Provinsi Sumatera Utara, Universitas Sumatera Utara, hal. 30

Irianto, K. 2014. Bakteriologi, Mikologi \& Virologi. I. Edited by F. Zulhendri. Bandung: CV ALFABETA.

Jawetz, Melnick \& Adelberg's. 2013. Medical Microbiology. $26^{\text {th }}$ ed. United States: The McGraw-Hill Companies. Jawetz, Melnick \& Adelberg. 2004. Mikrobiologi Kedokteran. $23^{\text {rd }}$ ed. Edited byR.
Saidah. Jakarta: Penerbit Buku Kedokteran EGC.

Jiwintarum, Y. et al. 2017. Media Alami Untuk Pertumbuhan Jamur Candida albicans Penyebab Kandidiasis dari Tepung Biji Kluwih (Artocarpus communis), Jurnal Kesehatan Prima, 11(2): hal. $158-170$

Laleye, S. A. et al. 2007. Growth of Some Microorganisms on Media Formulated From Local Raw Materials, Jurnal of Microbiology, 2(6), hal. 545-549.

Machmud, M. 2008. Teknik Penyimpanan dan Pemeliharaan Mikroba, Buletin AgroBio, 4(1): hal. 24-32

Magdalena, A. F. 2010. Dinamika Stok Ikan Teri Stolephorus indicus (Van Hasselt,1983) di Teluk Banten Kabupaten Serang Provinsi Banten, Institut Pertanian Bogor, hal. 59.

Nurhayati, T. et al. 2013. Pembuatan Pepton Secara Enzimatis Menggunakan Bahan Baku Jeroan Ikan Tongkol, JPHPI, 16.

Purwati, S. \& Rahayu, T. 2016. Pemanfaatan Sumber Karbohidrat Yang Berbeda (Umbi Suweg, Umbi Talas, Dan Umbi Kimpul) Sebagai Subtitusi Media NA (Nutrient Agar) Untuk Pertumbuhan Bakteri, Universitas Muhammadiyah Surakarta, hal. 13

Putri, M. H., Sukini \& Yodong. 2017. Mikrobiologi. I. Edited by A. Sosiawan dan Suparmi. Jakarta: Kementerian Kesehatan Indonesia.

Rossita, A. S., Munandar, K. \& Komarayanti, S. 2017. Comparison Of Medium NA Manufacturer with NA Modifications to the Growth Medium, Seminar Nasional Biologi, (1): hal. 192-201 
Rahmi, Y. et al. (2015). Identifikasi Bakteri

Staphylococcus
Preputium dan Vagina Kuda (Equus
caballus), Jurnal Media
$9(2)$.

Safitri, R. \& Novel, S. S. 2010. Medium Analisis Mikroorganisme. Edited by $\mathrm{H}$. Pramono \& H. Prayitno. Jakarta Timur: CV. Trans Info Media.

Salima, J. 2015. Antibacterial Activity of Garlic ( Allium sativum l .), 4, hal. 30-39

Sari, K. D. P. et al. 2017. Potensi Penggunaan Media Teknis Sebagai Pengganti Media Sea Water Complete (SWC) Untuk Mendukung Pertumbuhan Bakteri Bacillus sp. D2.2, Sains Teknologi Akuakultur, hal. 95-103

Saputra, D. \& Nurhayati, T. 2013. Produksi dan Aplikasi Pepton Ikan Selar untuk Media Pertumbuhan Bakteri, Perikanan dan Ilmu Kelautan, 16.

Sobari, M. et al. 2006. Kajian Aspek Bio-Teknik dan Finansial terhadap Pemanfaatan Sumberdaya Ikan Teri di Perairan
Pemekasan Madura, Buletin Ekonomi Perikanan.

Suhartati, Sulistiani \& Nuraini, A. 2018. Pemanfaatan Serbuk Kacang Kedelai (Glycine max) Sebagai Bahan Pembuatan Media Manitol Salt Agar (MSA) Untuk Pertumbuhan Bakteri Staphylococcus, Prosiding Seminar Nasional dan Diseminasi Penelitian Kesehatan, hal. 5

Syaifudin, dkk. 2008. Pemanfaatan Ikan Teri (Stolephrus sp.) yang Kaya Protein dan Kalsium dalam Formulasi Pembuatan Baso. Bogor (IDN): Institut Pertanian Bogor. hal. 22

Toelle, N. N. \& Lenda, V. 2014. Identifikasi dan Karakteristik Staphylooccus sp.dan Streptococcus $s p . \quad$ dari Infeksi Ovarium Pada Ayam Petelur Komersial, Ilmu Ternak, hal. 5

Wachidah, I. 2016. Pemanfaatan Umbi Gadung dan Umbi Uwi Sebagai Media Alternatif Substitusi Nutrient Agar (NA) Untuk Pertumbuhan Bakteri, hal. 15

\footnotetext{
${ }^{\square}$ Korespodensi: Tutur Mutmainnah Novitasari, titanelang@gmail.com, 081236301645, Jurnal Analis Medika Bio Sains, Volume X No. X, Februari X|
} 